Archives of Agriculture and Environmental Science

\title{
Effect of integrated nitrogen application on the yield of two Boro rice varieties: BRRI dhan29 and BRRI dhan74
}

\author{
Mst. Shirin Akter*, Sabina Yeasmin and Ahmed Khairul Hasan \\ Department of Agronomy, Bangladesh Agricultural University, Mymenshingh-2202, BANGLADESH \\ "Corresponding author's E-mail: bbijoya0@gmail.com
}

\section{ARTICLE HISTORY}

Received: 16 November 2018

Accepted: 06 December2018

\section{Keywords}

Inorganic fertilizer

Integrated nutrient management

Manure

Recommended dose

Vermicompost

\section{ABSTRACT}

This study aimed to evaluate the effect of integrated nitrogen $(N)$ application on the yield of Boro rice. The experiment was composed of two rice varieties: BRRI dhan29 and BRRI dhan74, and eleven $\mathrm{N}$ management approaches: control (without $\mathrm{N}$ ), 100\% varietal recommended dose (RD) of $\mathrm{N}$ from urea, $75 \%$ of RD from urea $+25 \%$ of RD from poultry manure (PM), $50 \%$ of RD from urea $+50 \%$ of RD from PM, $25 \%$ of RD from urea $+75 \%$ of RD from PM, 75\% of RD from urea $+25 \%$ of RD from vermicompost (VC), $50 \%$ of RD from urea $+50 \%$ of RD from VC, $25 \%$ of RD from urea $+75 \%$ of RD from VC, $75 \%$ of RD from urea $+25 \%$ of RD from cowdung (CD), $50 \%$ of RD from urea $+50 \%$ of RD from CD and $25 \%$ of RD from urea $+75 \%$ of RD from CD. Performance of BRRI dhan74 was better compared to BRRI dhan29 in terms of yield. For both verities, application of $75 \%$ of RD from urea $+25 \%$ of RD from PM produced the highest grain yield (BRRI dhan74: $3.30 \mathrm{t} \mathrm{ha}^{-1}$ and BRRI dhan29: $3.08 \mathrm{t} \mathrm{ha}^{-1}$ ) and the lowest with control among the $\mathrm{N}$ management approaches. Thus, it can be suggested that integrated $\mathrm{N}$ application with $75 \%$ of varietal RD from urea and $25 \%$ from PM in Boro rice cultivation will produce appreciable grain yield and also expected to have positive effect on soil health.

(C)2018 Agriculture and Environmental Science Academy

Citation of this article: Akter, M.S., Yeasmin, S. and Hasan, A.K. (2018). Effect of integrated nitrogen application on the yield of two Boro rice varieties: BRRI dhan29 and BRRI dhan74 Archives of Agriculture and Environmental Science, 3(4): 410-415, https:// dx.doi.org/10.26832/24566632.2018.0304014

\section{INTRODUCTION}

Rice is the main food crop of Bangladesh, accounting for about $75 \%$ of agricultural land use (BBS, 2015). There are three rice growing seasons namely Aus, Aman and Boro. The majority of rice growing area is covered by Boro rice comprising $58 \%$ of the total rice area (BBS, 2015). The yield of Boro rice is higher than that of Aman and Aus rice. Among the top rice growing countries of the world, the position of Bangladesh is forth (BBS, 2015). But there is still a yield gap between potential yield in research field and farmer's field. According to recent study conducted by Bangladesh Rice Research Institute (BRRI), the yield gap in rice production was estimated at $1.74 \mathrm{tha}^{-1}$. Yield gap between potential and farmer's yield are substantially high due to the combination of constraints, such as poor management, economic condition of farmers, lack of resources and knowledge. Exploiting the production potential of high yielding rice varieties through agronomic management is one of the major means to minimize the yield gap.
Fertilizers have contributed substantially to the spectacular increase in the yield of rice. Among all nutrient elements, Nitrogen $(N)$ is the most important fertilizer element playing vital role in yield improvement of rice and the element is frequently reported as deficient in agricultural soils of Bangladesh (Islam, 1990). However, growing crop with indiscriminate use of $N$ fertilizers by our farmers has resulted into degradation of lands owing to low yields with poor quality of produce. Moreover, continuous uses of chemical fertilizer cause negative impact on environment. The use of inorganic fertilizer to sustain cropping was found to increase yield only for some few years but on long-term, it has not been effective and lead to soil degradation (Satyanarayana et al., 2002). On the other hand, continuous application of organic fertilizer alone on rice field resulted low yield and low $\mathrm{N}$ and $\mathrm{K}$ contents at the tillering stage of rice plant (Javier et al., 2004). This implies that the integration of inorganic and organic fertilizers could act as a great way for practicing sustainable agriculture and to achieve food security. The 
integrated nutrient management system is characterized by reduced input of chemical fertilizers and combined use of chemical fertilizer with organic materials such as animal manures, crop residues, green manure and compost (Husan et al., 2014). Combined use of organic manures and inorganic fertilizers help in maintaining yield stability through correction of marginal deficiencies of secondary and micronutrients, enhancing efficiency of applied nutrients and providing favorable soil physical conditions (Gill and Walia, 2014) which may increase up to $50 \%$ of the world crop production (Pradhan, 1992). It has been reported that the use of organic fertilizer together with chemical fertilizer, compared to the addition of organic fertilizer alone, had a higher positive effect on microbial biomass and soil health (Dutta et al., 2003). Losses of $N$ from inorganic sources are very rapid from the soil through volatilization and de-nitrification. As a result, in near future, fertilizer $\mathrm{N}$ is likely to be even more costly. This situation in turn will pose a serious threat to food security for the vast millions of populations of the country, which again indicates to start using inorganic $\mathrm{N}$ fertilizer blended with organic manures to minimize the $\mathrm{N}$ loss by increasing $\mathrm{N}$ use efficiency by rice plant. Integrated $\mathrm{N}$ management increases long term productivity through sustaining soil productivity. Positive effect of integrated $\mathrm{N}$ application might help to motivate the growers in this system by reducing total production cost aims for efficient and judicious use of all the major sources of plant nutrients in an integrated manner (Farouque and Takeya, 2007). But still farmers of Bangladesh are not interested in integrated nutrient practices in rice field mainly due to deficiency of material, lack of knowledge about variation of $\mathrm{N}$ content in different organic manures, selecting best manures, their specific rate/ratio of integration with chemical fertilizer. In integrated nutrient management, calculation of the exact amount and combination of $\mathrm{N}$ from different sources is often critical, which put negative impact on farmer's decision in selecting integrated practice.

Therefore, the present study was undertaken to evaluate the differential varietal response on integrated $\mathrm{N}$ management practices, to determine the effect of integrated $\mathrm{N}$ application on growth and yield of rice and to determine the best combination of integrated N management for Boro rice cv. BRRI dhan29 and BRRI dhan74.

\section{MATERIALS AND METHODS}

\section{Experimental site and soil}

The experiment was conducted at the Agronomy Field Laboratory, Bangladesh Agricultural University, Mymensingh (located at $24^{\circ} 75^{\prime} \mathrm{N}$ latitude and $90^{\circ} 5^{\prime} \mathrm{E}$ longitude) belonging to the Old Brahmaputra Floodplain agro-ecological zone of Bangladesh (AEZ- 9) during December 2016 to May 2017. The topography of the experimental field was low to medium with moderate drainage facilities having non-calcareous dark gray floodplain soil (UNDP and FAO, 1988). The texture of the soil was loamy in nature with more or less neutral $(\mathrm{pH} 6.8)$ in reaction and low in $\mathrm{N}(0.1 \%)$ and exchangeable K (0.14\%) contents. Available P and $\mathrm{S}$ were 26.0 and $13.9 \mathrm{ppm}$, respectively and general fertility level was also low. The climate of experimental site was sub- tropical in nature which is characterized by high temperature, high humidity and heavy precipitation with occasionally gusty wind during Kharif season (April to September) and scanty rainfall associated with moderately low temperature during Rabi season (October to March).

\section{Experimental design and treatments}

The experiment consisted of two factors: A) two varieties and B) eleven $\mathrm{N}$ management approaches as follows:

\section{Factor A: variety- BRRI dhan29 and BRRI dhan74}

BRRI dhan29 was developed by Bangladesh Rice Research Institute (BRRI) in 1994, by crossing of BG-902 and BR51-45-5. The cultivar of BRRI dhan29 matures in 155-160 days. The grain is medium sized and golden yellow in color. Harvesting time is mid-April to early May and the average yield of the cultivar is $7.5 \mathrm{t}$ $\mathrm{ha}^{-1}$. This cultivar has the resistance against leaf blight and sheath blight. BRRI dhan74 was developed by BRRI through hybridization method in 2014. BRRI dhan74 matures in 145-147 days. The average yield of the cultivar is $7 \mathrm{tha}^{-1}$. The special quality of this variety is the protein (8.3\%) and amylose (24.2\%) contents of the grains.

\section{Factor B: N- management approaches}

Control (without $\mathrm{N}$ application) $\left(\mathrm{N}_{1}\right), 100 \%$ varietal recommended dose (RD) of $\mathrm{N}$ from urea $\left(\mathrm{N}_{2}\right), 75 \% \mathrm{~N}$ of RD from urea $+25 \%$ $\mathrm{N}$ of RD from poultry manure (PM) $\left(\mathrm{N}_{3}\right), 50 \% \mathrm{~N}$ of RD from urea $+50 \% \mathrm{~N}$ of RD from $\mathrm{PM}\left(\mathrm{N}_{4}\right), 25 \% \mathrm{~N}$ of RD from urea $+75 \% \mathrm{~N}$ of RD from $P M\left(\mathrm{~N}_{5}\right), 75 \% \mathrm{~N}$ of RD from urea $+25 \% \mathrm{~N}$ of RD from vermicompost (VC) $\left(\mathrm{N}_{6}\right), 50 \% \mathrm{~N}$ of RD from urea $+50 \% \mathrm{~N}$ of RD from $\mathrm{VC}\left(\mathrm{N}_{7}\right), 25 \% \mathrm{~N}$ of RD from urea $+75 \% \mathrm{~N}$ of RD from $\mathrm{VC}$ $\left(\mathrm{N}_{8}\right), 75 \% \mathrm{~N}$ of RD from urea $+25 \% \mathrm{~N}$ of RD from cowdung (CD) $\left(\mathrm{N}_{9}\right), 50 \% \mathrm{~N}$ of RD from urea $+50 \% \mathrm{~N}$ of RD from $\mathrm{C}\left(\mathrm{N}_{10}\right)$ and $25 \% \mathrm{~N}$ of RD from urea $+75 \% \mathrm{~N}$ of RD from $\mathrm{C}\left(\mathrm{N}_{11}\right)$.

[Here, for urea: $100 \%=263 \mathrm{~kg} \mathrm{ha}^{-1} ; 75 \%=197 \mathrm{~kg} \mathrm{ha}^{-1} ; 50 \%=$ $131 \mathrm{~kg} \mathrm{ha}^{-1} ; 25 \%=66 \mathrm{~kg} \mathrm{ha}^{-1}$; for PM: $75 \%=4323 \mathrm{~kg} \mathrm{ha}^{-1} ; 50 \%$ $=2882 \mathrm{~kg} \mathrm{ha}^{-1} ; 25 \%=1440 \mathrm{~kg} \mathrm{ha}^{-1}$; for VC: $75 \%=6052 \mathrm{~kg} \mathrm{ha}^{-1}$; $50 \%=4035 \mathrm{~kg} \mathrm{ha}^{-1} ; 25 \%=2017 \mathrm{~kg} \mathrm{ha}^{-1}$ and CD: $75 \%=7566 \mathrm{~kg}$ $\mathrm{ha}^{-1} ; 50 \%=5044 \mathrm{~kg} \mathrm{ha}^{-1} ; 25 \%=2521 \mathrm{~kg} \mathrm{ha}^{-1}$ ]

The experiment was conducted in Randomized Complete Block Design (RCBD) with three replications. The size of each unit plot was $5 \mathrm{~m}^{2}(2.5 \mathrm{~m} \times 2 \mathrm{~m})$. The space between block to block and plot to plot was $1 \mathrm{~m}$ and $0.5 \mathrm{~m}$, respectively.

\section{Crop husbandry}

The experimental land was opened with a power tiller and then puddled thoroughly by ploughing. Weeds and stubble of the previous crop were collected and removed from the field. Both organic and inorganic fertilizers were applied according to the treatments. Urea was applied into three equal splits. The first split of urea, triple super phosphate (TSP), muriate of potash (MoP), gypsum and other organic manure ( $P M, V C$ and $C D$ ) were at the time of final land preparation as per treatment. The second split of urea was top dressed at 30 days after transplanting (DAT) and third split of urea was top dressed at 60 DAT (Panicle initiation stage). Organic manures were analyzed 
(micro Kjeldahl method) in the laboratory for $\mathrm{N}$ content and found $2.1 \%, 1.5 \%$ and $1.2 \% \mathrm{~N}$ in PM, VC and CD, respectively.

Thirty-five days old seedlings were then transplanted in rows in the main field at the rate of three seedlings hill ${ }^{-1}$ with $25 \mathrm{~cm} \times 15$ $\mathrm{cm}$ spacing. Intercultural operations- gap filling, weeding, irrigation and drainage have been done as when necessary. The crop was harvested at full maturity. The harvested crop of each plot was separately bundled, properly tagged and the fresh weights of grain straw were recorded plot wise. The grains were cleaned and sun dried to a moisture content of $14 \%$.

\section{Data collection and statistical analysis}

Five random hills of each plot were selected to record plant height, total tillers hill-1, effective tillers $\mathrm{hll}^{-1}$, number of sterile spikelet panicle ${ }^{-1}$ and grains panicle ${ }^{-1}$; and 1000-grain weight, grain + straw yields, biological yield and harvest index of each plot were recorded from the whole plot at harvest. The recorded data on yield and yield contributing characters were statistically analyzed using "Analysis of Variance" technique following two factors RCBD computer package MSTAT. The mean differences among treatments means were tested by Duncan's New Multiple Range Test (DMRT).

\section{RESULTS AND DISCUSSION}

Varietal effect on yield and yield contributing characters All the yield and yield contributing characters except number of sterile spikelet panicle ${ }^{-1}$ were significantly influenced by the variety (Table 1 and Figure 1). Performance of BRRI dhan74 was

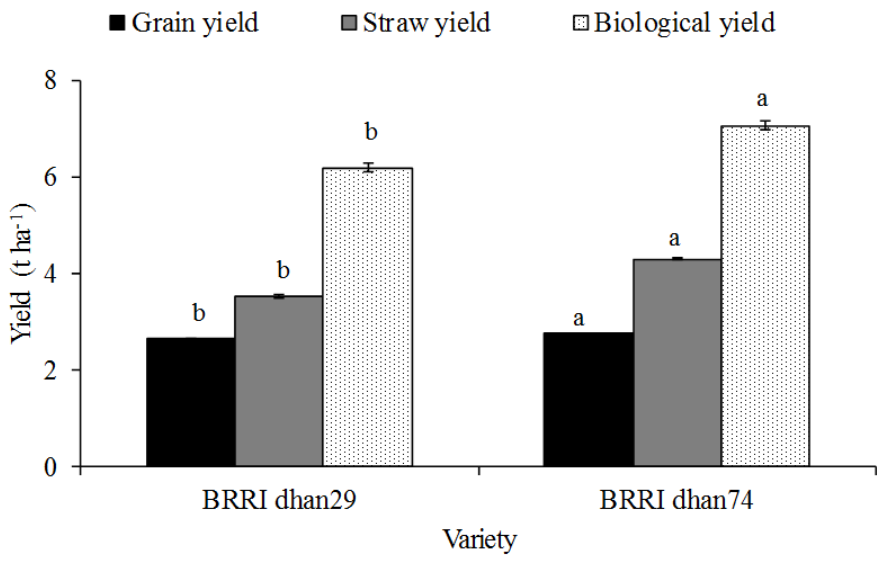

Figure 1. Effect of variety on grain, straw and biological yields of BRRI dhan 29 and BRRI dhan74. Error bars in the figure represent the standard error of three replications. Column with same letter do not differ significantly whereas figures with dissimilar letter differ significantly $(p<0.01)$. better compared to BRRI dhan29 in terms of all parameters. BRRI dhan74 produced the taller plant $(89.00 \mathrm{~cm})$ than the BRRI dhan29 $(81.10 \mathrm{~cm})$ (Table 1). Higher (10.12) number of total tillers hill $^{-1}$, effective tillers hill $^{-1}$ (9.09) and grains panicle ${ }^{-1}$ (97.74) was produced by BRRI dhan74 than BRRI dhan29 (number of total tillers hill ${ }^{-1}: 9.70$, effective tillers hill $^{-1}: 8.65$ and grains panicle ${ }^{-1}$ : 94.33). The varietal differences might be due to heredity or varietal character (Hossain et al., 2003; Kabir et al., 2004; Kamal et al., 1999). Numerically BRRI dhan29 gave the higher (6.32) number of sterile spikelet panicle ${ }^{-1}$ than BRRI dhan74 (6.01). Weight of 1000 grains (g) was $34.10 \mathrm{~g}$ in BRRI dhan74 and $24.28 \mathrm{~g}$ in BRRI dhan29. BRRI dhan74 gave higher grain (2.75 $\left.\mathrm{tha}^{-1}\right)$, straw (4.30 $\left.\mathrm{t} \mathrm{ha}^{-1}\right)$ and biological (7.05 $\mathrm{t} \mathrm{ha}^{-1}$ ) yields compared to BRRI dhan29 (2.65 $\mathrm{t} \mathrm{ha}^{-1}, 3.53$ and $6.18 \mathrm{t} \mathrm{ha}^{-1}$ of grain, straw and biological yields, respectively) (Figure 1). Similar results were also reported by Hossain et al. (2003) and Kabir et al. (2004). Harvest index was higher in BRRI dhan29 (42.86\%) than BRRI dhan74 (39.28\%).

Effect of nitrogen management approaches on yield and yield contributing characters

All the yield and yield contributing characters except harvest index were significantly influenced by $\mathrm{N}$ management approaches (Table 2). The tallest $(88.07 \mathrm{~cm})$ plant was observed from applying $25 \% \mathrm{~N}$ of RD from urea $+75 \% \mathrm{~N}$ of RD from VC $\left(\mathrm{N}_{8}\right)$ which was statistically identical to $\mathrm{N}_{7}(50 \% \mathrm{~N}$ of $\mathrm{RD}$ from urea + $50 \%$ of RD from VC). The shortest $(81.27 \mathrm{~cm})$ plant height was found from control $\left(\mathrm{N}_{1}\right)$. The highest number of total tiller hill ${ }^{-1}$ (10.97) was found in case of $\mathrm{N}_{3}$, i.e., $75 \% \mathrm{~N}$ of RD from urea + $25 \% \mathrm{~N}$ of RD from PM and the lowest (9.17) was observed in control. Usman et al. (2003) also reported maximum number of tillers hill $^{-1}$ from the combined application of urea and PM (50 kg $\mathrm{N}$ ha ${ }^{-1}+20 \mathrm{t} \mathrm{ha}^{-1} \mathrm{PM}$ ). Maximum number (10.30) of effective tillers hill ${ }^{-1}$ was obtained from the application of $75 \% \mathrm{~N}$ of RD from Urea $+25 \% \mathrm{~N}$ of RD from PM $\left(\mathrm{N}_{3}\right)$ and the lowest (7.70) was found in control. The highest no. of grain panicle ${ }^{-1}, 1000$ grain weight $(30.35 \mathrm{~g})$, grain yield $\left(3.19 \mathrm{t} \mathrm{ha}^{-1}\right)$, straw yield $(5.02 \mathrm{t}$ $\left.\mathrm{ha}^{-1}\right)$, biological yield $\left(8.21 \mathrm{tha}^{-1}\right)$ was observed in $75 \% \mathrm{~N}$ of RD from Urea $+25 \% \mathrm{~N}$ of RD from $\mathrm{PM}\left(\mathrm{N}_{3}\right)$. The result agreed with Dwivedi et al. (2000) who reported higher grain yield of rice from integrated application of organic and inorganic fertilizers than sole application of inorganic fertilizer. Similar results were also reported by Sarkar et al. (2007), Islam et al. (2007) and Sarkar et al. (2016).

Table 1. Effect of variety on yield and yield contributing characters of transplanted Boro rice.

\begin{tabular}{|c|c|c|c|c|c|c|c|}
\hline Variety & $\begin{array}{l}\text { Plant } \\
\text { height } \\
\text { (cm) }\end{array}$ & $\begin{array}{l}\text { No. of } \\
\text { total tillers } \\
\text { hill }^{-1}\end{array}$ & $\begin{array}{l}\text { No. of } \\
\text { effective } \\
\text { tillers hill }^{-1}\end{array}$ & $\begin{array}{l}\text { No. of grains } \\
\text { Panicle }^{-1}\end{array}$ & $\begin{array}{l}\text { No. of } \\
\text { sterile } \\
\text { spikelet } \\
\text { Panicle }^{-1}\end{array}$ & $\begin{array}{l}1000 \text { grain } \\
\text { weight }(g)\end{array}$ & $\begin{array}{l}\text { Harvest } \\
\text { index (\%) }\end{array}$ \\
\hline BRRI dhan29 & $89.00 \mathrm{a}$ & $9.70 \mathrm{~b}$ & $8.65 \mathrm{~b}$ & $94.33 \mathrm{~b}$ & 6.32 & $24.28 \mathrm{~b}$ & $42.86 a$ \\
\hline BRRI dhan74 & $81.10 \mathrm{~b}$ & $10.12 \mathrm{a}$ & $9.09 a$ & $97.74 a$ & 6.01 & $34.10 \mathrm{a}$ & $39.28 b$ \\
\hline Standard error & 0.588 & 0.078 & 0.044 & 0.527 & 0.143 & 0.161 & 0.233 \\
\hline Level of significance & $* *$ & $* *$ & $* *$ & $* *$ & NS & $* *$ & $* *$ \\
\hline CV (\%) & 3.97 & 4.54 & 2.84 & 3.15 & 13.33 & 3.17 & 3.27 \\
\hline
\end{tabular}

In a column, figures with same letter (s) or without letter do not differ significantly whereas figures with dissimilar letter differ significantly (as per DMRT). ${ }^{* *}=$ Significant at probability level ( $p$ ) 0.01 , NS = Non-significant and CV=coefficient of variation. 
Table 2. Effect of nitrogen $(\mathrm{N})$ management approaches on yield and yield contributing characters of transplanted Boro rice.

\begin{tabular}{|c|c|c|c|c|c|c|c|c|c|c|}
\hline $\begin{array}{l}\mathrm{N} \text { management } \\
\text { approaches }\end{array}$ & $\begin{array}{l}\text { Plant } \\
\text { height } \\
(\mathrm{cm})\end{array}$ & $\begin{array}{c}\text { No. of } \\
\text { total } \\
\text { tillers } \\
\text { hill }^{-1}\end{array}$ & $\begin{array}{c}\text { No. of } \\
\text { effective } \\
\text { tillers } \\
\text { hill }^{-1}\end{array}$ & $\begin{array}{c}\text { No. of } \\
\text { grains } \\
\text { Panicle }^{-1}\end{array}$ & $\begin{array}{l}\text { No. of } \\
\text { sterile } \\
\text { spikelet } \\
\text { Panicle }^{-1}\end{array}$ & $\begin{array}{c}1000 \\
\text { grain } \\
\text { weight } \\
\text { (g) }\end{array}$ & $\begin{array}{l}\text { Grain } \\
\text { yield } \\
\left(\mathrm{t} \mathrm{ha}^{-1}\right)\end{array}$ & $\begin{array}{l}\text { Straw } \\
\text { yield } \\
\left(\mathrm{t} \mathrm{h} \mathrm{h}^{-1}\right)\end{array}$ & $\begin{array}{c}\text { Biological } \\
\text { yield } \\
\left(\mathrm{t} \mathrm{ha}^{-1}\right)\end{array}$ & $\begin{array}{c}\text { Harvest } \\
\text { index (\%) }\end{array}$ \\
\hline $\mathrm{N}_{1}$ & $81.37 c$ & $9.17 d$ & $7.70 \mathrm{e}$ & $87.67 \mathrm{e}$ & $7.22 a$ & $27.90 \mathrm{e}$ & $2.40 \mathrm{~h}$ & $3.32 \mathrm{~g}$ & $5.72 \mathrm{i}$ & 42.00 \\
\hline $\mathrm{N}_{2}$ & 84.97abc & $10.07 \mathrm{bc}$ & $9.23 c$ & 99.31ab & $5.88 \mathrm{bc}$ & $29.75 a b c$ & $2.85 c$ & $4.06 c$ & $6.91 b c$ & 41.22 \\
\hline $\mathrm{N}_{3}$ & 86.03ab & $10.97 a$ & $10.30 a$ & 101.10a & $5.26 c$ & $30.35 a$ & $3.19 a$ & $5.02 a$ & $8.21 a$ & 39.96 \\
\hline $\mathrm{N}_{4}$ & $82.10 b c$ & $9.73 \mathrm{~cd}$ & $8.57 d$ & $95.48 \mathrm{bcd}$ & 6.27abc & 29.05b-e & $2.61 f$ & 3.81de & 6.42efg & 40.61 \\
\hline $\mathrm{N}_{5}$ & $84.90 a b c$ & $9.59 \mathrm{~cd}$ & $8.43 d$ & $94.91 \mathrm{~cd}$ & 6.31abc & $28.85 b-e$ & $2.52 \mathrm{~g}$ & 3.71ef & $6.23 f g$ & 40.32 \\
\hline $\mathrm{N}_{6}$ & $86.10 a b$ & $10.57 a b$ & $9.90 \mathrm{~b}$ & 101.00a & $5.67 \mathrm{bc}$ & $29.95 a b$ & $2.91 b$ & $4.24 b$ & $7.16 b$ & 41.23 \\
\hline $\mathrm{N}_{7}$ & $86.90 a$ & $9.96 c$ & $8.97 c$ & $97.10 b c$ & $6.11 b c$ & $29.25 a-d$ & $2.75 d$ & $3.98 \mathrm{~cd}$ & $6.73 \mathrm{cde}$ & 41.10 \\
\hline $\mathrm{N}_{8}$ & $88.07 a$ & $9.80 c$ & $8.63 d$ & $96.08 \mathrm{bc}$ & $6.15 a b c$ & $29.20 a-d$ & $2.66 \mathrm{e}$ & $3.90 \mathrm{~cd}$ & 6.56def & 40.46 \\
\hline $\mathrm{N}_{9}$ & $85.33 a b c$ & $10.02 b c$ & $9.14 c$ & 97.89abc & $6.01 b c$ & 29.70a-d & $2.80 \mathrm{~d}$ & $4.02 c$ & $6.82 \mathrm{~cd}$ & 41.19 \\
\hline $\mathrm{N}_{10}$ & 86.10ab & $9.58 \mathrm{~cd}$ & $8.40 d$ & $94.23 \mathrm{~cd}$ & $6.41 a b$ & $28.60 \mathrm{cde}$ & $2.51 \mathrm{~g}$ & $3.60 f$ & 6.11gh & 41.24 \\
\hline $\mathrm{N}_{11}$ & 83.77abc & $9.56 \mathrm{~cd}$ & $8.33 d$ & $91.65 d$ & $6.47 a b$ & $28.50 \mathrm{de}$ & $2.47 \mathrm{~g}$ & $3.37 \mathrm{~g}$ & $5.85 \mathrm{hi}$ & 42.44 \\
\hline Standard error & 1.38 & 0.18 & 0.10 & 1.24 & 0.34 & 0.38 & 0.02 & 0.06 & 0.11 & 0.55 \\
\hline $\begin{array}{l}\text { Level of } \\
\text { significance }\end{array}$ & * & $* *$ & $* *$ & $* *$ & $*$ & $* *$ & $* *$ & $* *$ & $* *$ & NS \\
\hline CV (\%) & 3.97 & 4.54 & 2.84 & 3.15 & 13.33 & 3.17 & 1.83 & 3.70 & 4.01 & 3.27 \\
\hline
\end{tabular}

${ }^{* *}$ Significant at probability level $(p) 0.01,{ }^{*}=$ Significant at probability level $(p) 0.05$, NS = Not significant, $\mathrm{CV}=$ coefficient of variation, $\mathrm{N}_{1}=$ control; $\mathrm{N}_{2}=$ $100 \%$ recommended dose (RD) of $\mathrm{N}$ from urea; $\mathrm{N}_{3}=75 \% \mathrm{~N}$ of RD from urea $+25 \% \mathrm{~N}$ of RD from poultry manure (PM); $\mathrm{N}_{4}=50 \% \mathrm{~N}$ of RD from urea + $50 \% \mathrm{~N}$ of RD from PM; $\mathrm{N}_{5}=25 \% \mathrm{~N}$ of RD from urea $+75 \% \mathrm{~N}$ of RD from PM; $\mathrm{N}_{6}=75 \% \mathrm{~N}$ of RD from urea $+25 \% \mathrm{~N}$ of RD from vermicompost (VC); $\mathrm{N}_{7}$ $=50 \% \mathrm{~N}$ of RD from urea $+50 \% \mathrm{~N}$ of RD from $\mathrm{VC} ; \mathrm{N}_{8}=25 \% \mathrm{~N}$ of RD from urea $+75 \% \mathrm{~N}$ of RD from $\mathrm{VC} ; \mathrm{N}_{9}=75 \% \mathrm{~N}$ of RD from urea $+25 \% \mathrm{~N}$ of RD from cowdung (CD); $\mathrm{N}_{10}=50 \% \mathrm{~N}$ of RD from urea $+50 \% \mathrm{~N}$ of RD from CD; $\mathrm{N}_{11}=25 \% \mathrm{~N}$ of RD from urea $+75 \% \mathrm{~N}$ of RD from CD.

Interaction effect of nitrogen management approaches on yield and yield contributing characters

Interaction effect of variety and $\mathrm{N}$ management approaches was significant on the yields of Boro rice but was non-significant on yield contributing characters except no. of effective tillers hill ${ }^{-1}$ (Table 3). However, numerically the highest no. of tillers hill ${ }^{-1}$ (11.13) was observed in BRRI dhan74 with the combination of $100 \% N$ of $R D$ from urea $\left(N_{2}\right)$ and the lowest (9.07) was observed in BRRI dhan29 with control $\left(\mathrm{N}_{1}\right)$ treatment (Table 3). The highest no. of effective tillers hill ${ }^{-1}(10.6)$ was observed in BRRI dhan74 with the combination $75 \% \mathrm{~N}$ of RD from urea + $25 \% \mathrm{~N}$ of RD from PM $\left(\mathrm{N}_{3}\right)$ and lowest (7.47) was found in BRRI dhan29 in control treatment. The result was in agreement with the findings of Lawal and Lawal (2002). The $\mathrm{N}_{3}$ management approach combined with BRRI dhan74 produced the highest (3.30 $\mathrm{t} \mathrm{ha}^{-1}$ ) grain yield and straw yield $\left(6.15 \mathrm{t} \mathrm{ha}^{-1}\right)$ the lowest (2.36 $\mathrm{t} \mathrm{ha}^{-1}$ and $2.99 \mathrm{t} \mathrm{ha}^{-1}$ of grain and straw yields, respectively) one was observed in combination of BRRI dhan29 with control (Table 3). Even for BRRI dhan29, the highest yields (3.08 and $3.89 \mathrm{t} \mathrm{ha}^{-1}$ of grain and straw, respectively) was produced from the same $\mathrm{N}$ management approaches, i.e., 75\% $\mathrm{N}$ of RD from urea $+25 \% \mathrm{~N}$ of RD from PM. Harvest index was highest (44.88\%) in BRRI dhan29 with the combination of $25 \% \mathrm{~N}$ of RD from urea $+75 \% \mathrm{~N}$ of RD from $\mathrm{CD}\left(\mathrm{N}_{11}\right)$ and the lowest (34.91\%) one was in BRRI dhan74 with the combined application of $75 \%$
$\mathrm{N}$ of RD from urea $+25 \% \mathrm{~N}$ of RD from PM $\left(\mathrm{N}_{3}\right)$. Rahman et. al. (2009) and Yeasmin et al. (2009) also reported higher grain yield from the combined use of urea $\mathrm{N}$ and manure (PM and $C D$ ) than only urea-N application. Similar results were also obtained by Sarkar et al. (2007), Islam et al. (2007) and Sarkar et al. (2016).

From the above results it is perceived that the integrated application of $75 \% \mathrm{~N}$ of RD from urea $+25 \% \mathrm{~N}$ of RD from PM $\left(\mathrm{N}_{3}\right)$ for both varieties, BRRI dhan29 and BRRI dhan74 was the best combination to obtain highest grain yield in Boro season. Poultry manure as an organic source of $\mathrm{N}$ combined with urea performed better than all other organic sources (VC and CD) possibly because of the higher $\mathrm{N}$ (+ other nutrient) content of PM than VC and CD which might cause increased $N$ and other nutrient availability in soil and uptake of nutrients by rice plants. The PM along with urea fertilizer helped to increase the uptake of the major nutrients which promoted satisfactory growth of plant (Mohamoud et al., 2002). Ranjitha et al. (2013) claimed maximum NPK uptake by rice from the integrated application of organic + inorganic $\mathrm{N}$ fertilizers. This adequate nutrient supply might be attributed to the greater partitioning of dry matter into economic part (Vajanthaa et al., 2012). Apart from economic return, combined use of organic and inorganic fertilizers is very helpful for maintaining a long-term soil fertility and crop productivity (Eghball et al., 2005). 
Table 3. Interaction effects of variety and nitrogen $(\mathrm{N})$ management approaches on yield and yield contributing characters of Boro rice.

\begin{tabular}{|c|c|c|c|c|c|c|c|c|c|c|}
\hline $\begin{array}{l}\text { Interaction } \\
\text { (variety } \times \mathrm{N} \\
\text { management } \\
\text { approaches) }\end{array}$ & $\begin{array}{l}\text { Plant } \\
\text { height } \\
\text { (cm) }\end{array}$ & $\begin{array}{l}\text { No. of } \\
\text { total } \\
\text { tillers } \\
\text { hill }^{-1}\end{array}$ & $\begin{array}{c}\text { No. of } \\
\text { effective } \\
\text { tillers hill }^{-1}\end{array}$ & $\begin{array}{c}\text { No. of } \\
\text { grains } \\
\text { Panicle }^{-1}\end{array}$ & $\begin{array}{c}\text { No. of } \\
\text { sterile } \\
\text { spikelet } \\
\text { panicle }^{-1}\end{array}$ & $\begin{array}{c}1000 \\
\text { grain } \\
\text { weight } \\
\text { (g) }\end{array}$ & $\begin{array}{l}\text { Grain yield } \\
\qquad\left(\mathrm{t} \mathrm{ha}^{-1}\right)\end{array}$ & $\begin{array}{l}\text { Straw } \\
\text { yield } \\
\left(\mathrm{t} \mathrm{h} \mathrm{h}^{-1}\right)\end{array}$ & $\begin{array}{c}\text { Biological } \\
\text { yield } \\
\left(\mathrm{t} \mathrm{ha}^{-1}\right)\end{array}$ & $\begin{array}{l}\text { Harvest } \\
\text { index (\%) }\end{array}$ \\
\hline $\mathrm{V}_{1} \times \mathrm{N}_{1}$ & 84.90 & 9.07 & $7.47 j$ & 85.05 & 7.46 & 22.90 & $2.36 \mathrm{~m}$ & $2.99 j$ & 5.361 & 44.07ab \\
\hline $\mathrm{V}_{1} \times \mathrm{N}_{2}$ & 91.60 & 9.93 & $9.13 c d$ & 98.27 & 5.92 & 24.70 & $2.80 \mathrm{ef}$ & 3.77efg & $6.56 \mathrm{e}-\mathrm{i}$ & $42.60 a-d$ \\
\hline $\mathrm{V}_{1} \times \mathrm{N}_{3}$ & 91.50 & 10.80 & $10.00 \mathrm{~b}$ & 98.92 & 5.54 & 25.70 & $3.08 \mathrm{~b}$ & 3.89ef & 6.97cde & $44.31 \mathrm{ab}$ \\
\hline $\mathrm{V}_{1} \times \mathrm{N}_{4}$ & 84.60 & 9.60 & 8.47fgh & 94.05 & 6.43 & 24.20 & $2.61 \mathrm{ij}$ & $3.46 \mathrm{hi}$ & $6.07 \mathrm{ijk}$ & 43.16ab \\
\hline $\mathrm{V}_{1} \times \mathrm{N}_{5}$ & 89.90 & 9.33 & 8.20ghi & 93.25 & 6.49 & 23.90 & $2.50 \mathrm{kl}$ & 3.45hi & $5.95 \mathrm{jk}$ & $42.01 b-f$ \\
\hline $\mathrm{V}_{1} \times \mathrm{N}_{6}$ & 90.60 & 10.07 & $9.27 c$ & 98.68 & 5.85 & 25.10 & $2.85 \mathrm{de}$ & 3.87ef & $6.72 d-h$ & 42.44a-e \\
\hline $\mathrm{V}_{1} \times \mathrm{N}_{7}$ & 88.30 & 9.80 & 8.80def & 95.13 & 6.22 & 24.30 & 2.68ghi & $3.71 \mathrm{e}-\mathrm{h}$ & $6.39 \mathrm{~g}-\mathrm{j}$ & $41.97 b-f$ \\
\hline $\mathrm{V}_{1} \times \mathrm{N}_{8}$ & 91.70 & 9.60 & $8.53 \mathrm{e}-\mathrm{h}$ & 94.58 & 6.28 & 24.30 & $2.63 \mathrm{hij}$ & $3.58 \mathrm{gh}$ & $6.21 \mathrm{ijk}$ & 42.38a-e \\
\hline $\mathrm{V}_{1} \times \mathrm{N}_{9}$ & 89.50 & 9.87 & $9.00 \mathrm{cde}$ & 95.86 & 6.18 & 24.60 & $2.73 f g$ & 3.74efg & $6.47 f-i$ & $42.20 \mathrm{~b}-\mathrm{e}$ \\
\hline $\mathrm{V}_{1} \times \mathrm{N}_{10}$ & 89.40 & 9.33 & 8.20ghi & 92.72 & 6.57 & 23.80 & $2.47 \mathrm{kl}$ & $3.32 i$ & $5.79 \mathrm{kl}$ & 42.64abc \\
\hline $\mathrm{V}_{1} \times \mathrm{N}_{11}$ & 87.10 & 9.33 & $8.13 \mathrm{hi}$ & 91.14 & 6.61 & 23.60 & $2.45 \mathrm{I}$ & $3.01 \mathrm{j}$ & $5.47 \mid$ & $44.88 a$ \\
\hline $\mathrm{V}_{2} \times \mathrm{N}_{1}$ & 77.70 & 9.27 & $7.90 i$ & 90.28 & 6.99 & 32.90 & $2.44 \mid$ & $3.65 \mathrm{fgh}$ & $6.09 \mathrm{ijk}$ & $40.04 c-g$ \\
\hline $\mathrm{V}_{2} \times \mathrm{N}_{2}$ & 78.30 & 10.20 & $9.33 c$ & 100.36 & 5.85 & 34.80 & $2.91 \mathrm{~cd}$ & $4.35 c$ & $7.26 b c$ & $40.08 \mathrm{c}-\mathrm{g}$ \\
\hline $\mathrm{V}_{2} \times \mathrm{N}_{3}$ & 80.60 & 11.13 & $10.60 \mathrm{a}$ & 103.29 & 4.99 & 35.00 & $3.30 a$ & $6.15 a$ & $9.45 a$ & $34.91 \mathrm{~h}$ \\
\hline $\mathrm{V}_{2} \times \mathrm{N}_{4}$ & 79.60 & 9.87 & $8.66 \mathrm{~d}-\mathrm{g}$ & 96.90 & 6.12 & 33.90 & $2.61 \mathrm{ij}$ & $4.17 \mathrm{~cd}$ & $6.78 c-g$ & $38.51 \mathrm{~g}$ \\
\hline $\mathrm{V}_{2} \times \mathrm{N}_{5}$ & 79.90 & 9.85 & $8.66 \mathrm{~d}-\mathrm{g}$ & 96.57 & 6.15 & 33.80 & $2.55 \mathrm{jk}$ & 3.97de & $6.52 \mathrm{e}-\mathrm{i}$ & $39.15 \mathrm{~g}$ \\
\hline $\mathrm{V}_{2} \times \mathrm{N}_{6}$ & 81.60 & 11.07 & $10.50 a$ & 103.24 & 5.51 & 34.80 & $2.98 c$ & $4.62 b$ & $7.60 \mathrm{~b}$ & $39.22 \mathrm{~g}$ \\
\hline $\mathrm{V}_{2} \times \mathrm{N}_{7}$ & 85.50 & 10.13 & $9.13 \mathrm{~cd}$ & 99.06 & 6.02 & 34.20 & $2.82 \mathrm{e}$ & $4.25 c$ & $7.07 \mathrm{~cd}$ & 39.89efg \\
\hline $\mathrm{V}_{2} \times \mathrm{N}_{8}$ & 84.50 & 10.00 & 8.73def & 97.58 & 6.02 & 34.10 & $2.70 \mathrm{gh}$ & $4.22 \mathrm{~cd}$ & 6.91c-f & $39.01 \mathrm{~g}$ \\
\hline $\mathrm{V}_{2} \times \mathrm{N}_{9}$ & 81.10 & 10.17 & $9.27 c$ & 99.92 & 5.86 & 34.80 & $2.87 \mathrm{de}$ & $4.30 c$ & 7.17bcd & $40.02 \mathrm{~d}-\mathrm{g}$ \\
\hline $\mathrm{V}_{2} \times \mathrm{N}_{10}$ & 82.80 & 9.83 & $8.60 \mathrm{e}-\mathrm{h}$ & 95.74 & 6.25 & 33.40 & $2.55 \mathrm{jk}$ & $3.88 \mathrm{ef}$ & $6.43 f-j$ & $39.58 f g$ \\
\hline $\mathrm{V}_{2} \times \mathrm{N}_{11}$ & 80.50 & 9.80 & $8.53 e-h$ & 92.16 & 6.34 & 33.40 & $2.50 \mathrm{kl}$ & 3.74efg & $6.24 \mathrm{~h}-\mathrm{k}$ & $40.08 d-g$ \\
\hline $\begin{array}{l}\text { Standard } \\
\text { error }\end{array}$ & 1.95 & 0.26 & 0.15 & 1.75 & 0.47 & 0.53 & 0.03 & 0.08 & 0.15 & 0.78 \\
\hline $\begin{array}{l}\text { Level of } \\
\text { significance }\end{array}$ & NS & NS & $*$ & NS & NS & NS & $*$ & $* *$ & $* *$ & $* *$ \\
\hline CV (\%) & 3.97 & 4.54 & 2.84 & 3.15 & 13.33 & 3.17 & 1.83 & 3.70 & 4.01 & 3.27 \\
\hline
\end{tabular}

Conclusion

This study concluded that BRRI dhan74 performed better than BRRI dhan29 in terms of yield. Integrated application of $75 \% \mathrm{~N}$ of RD from urea $+25 \% \mathrm{~N}$ of RD from PM was the best $\mathrm{N}$ management approach for Boro rice cV. BRRI dhan29 and BRRI dhan74 to obtain highest grain yield. However, this approach needs to be tested in different locations of Bangladesh before making final inference.

Open Access: This is an open access article distributed under the terms of the Creative Commons Attribution 4.0 License, which permits unrestricted use, distribution, and reproduction in any medium, provided the original author(s) if the sources are credited.

\section{REFERENCES}

BBS, Bangladesh Bureau of Statistics. (2015). Statistical year book of Bangladesh, Statistics Division. Ministry of Planning, Government of People Republic of Bangladesh. pp. 129-134.

Dutta, S., Pal, R., Chakeraborty, A. and Chakrabarti, K. (2003). Influence of integrated plant nutrient supply system on soil quality restoration in a red and laterite soil. Archives of Agronomy and Soil Science, 49(6): 631- 637.

Dwivedi, D.K. and Thakur, S.S. (2000). Effects of organic and inorganic fertilizer level on productivity of rice crop. Indian Journal of Agronomy, 45: 568-574.
Eghball, B., Ginting, D. and Gilleya, J.E. (2005). Residual effects of manure and compost applications on corn production and soil properties. Biological Systems Engineering, 96(2): 442-447.

Farouque, M. and Takeya, H. (2007). Farmers' perception of integrated soil fertility and nutrient management for sustainable crop production. A study of rural areas in Bangladesh. Journal of Agricultural Education, 48(3): 111-122.

Gill, J.S. and Walia, S.S. (2014). Influence of farm yard manure, brown manuring and nitrogen levels on direct seeded and transplanted rice (Oryza sativa L.). Research Journal of Agriculture and Environmental Management, 49(3): 417-426.

Hossain, M.S., Mamun, A.A., Basak, R., Newaj, M.N. and Anam, M.K. (2003). Effect of cultivar and spacing on weed infestation of Boro rice in Bangladesh. Pakistan Journal of Agronomy, 2: 169-178.

Husan, M.R., Faried, K. and Mian, M.H. (2014). Nitrogen use efficiency and rice yield as influenced by the application of prilled urea and urea super granule with or without organic manure. Journal of Bangladesh Agricultural University, 12(1): 37-43.

Islam, A.K.M.M. and Sarkar, M.A.R. (2007). Effect of spacings and nutrient management in SRI method on the yield components and yield of transplant aman rice. Bangladesh Journal of Crop Science, 18(1): 1-6.

Islam, M.S. (1990). Nutrient status of some soils of Bangladesh. In: Proceeding of International symposium on paddy soil fertility. Bangladesh Agricultural Research Council, Dhaka, Bangladesh, pp. 23-43. 
Javier, E.F, Marquez, J.M, Grospe, F.S, Mamucod, H.F. and Tabien, R.E. (2004). Three-year effect of organic fertilizer use on paddy rice. Philippine Journal of Crop Sciences, 27: 11-15.

Kabir, M.E., Kabir, M.R., Jahan, M.S. and Das, G.G. (2004). Yield performance of three aromatic fine rice in a coastal medium high land. Asian Journal of Plant Science, 3(5): 561-563.

Kamal, A.M.A., Islam, M.R. and Chowdhury, B.L.D. (1999). Growth performance and nutrient uptake by modern varieties of rice under irrigation condition in Bangladesh. Thailand Journal of Agricultural Science, 32: 105-110.

Lawal, M.I. and Lawal, A.B. (2002). Influence of nitrogen rate and placement method on growth and yield of rice (Oryza sativa) in Tamil Nadu. Indian Journal of Training Development, 23(3): 203-210.

Mohamoud, A.I. and Reddy, P.J. (2002). Effect of composts and fertilizer levels on the structure of growth and yield in maize (Zea mays L.). Madras Agricultural Journal, 89 (1\&2):720-3.

Pradhan, S.D. (1992). Status of fertilizer use in developing countries of Asia and the Pacific Region. Proceeding Region, FADINAP Seminar, Chiang Mai, Thailand. pp. 37-47.

Rahman, M.S., Islam, M.R., Rahman, M.M. and Hossain, M.I. (2009). Effect of cowdung, Poultry manure and Urea-N on the yield and nutrient uptake of BRRI Dhan-29. Bangladesh Research Publications Journal, 2(2): 552-558.

Ranjitha, P.S., Kumar, R.M., and Jayasree, G. (2013). Evaluation of rice (Oryza sativa L.) Varieties and hybrids in relation to different nutrient management practices for yield, Nutrient uptake and economics in SRI. Annuals of Biological Research, 4: 25-28.
Sarkar, M.A.R., Rahman, M.H. and Islam, A.K.M.M. (2007). Effect of combination of poultry manure and inorganic fertilizer on the yield and yield contributing characters of transplant aman rice. Bangladesh Journal Crop Science, 18(1): 7-12.

Sarkar, M.A.R., Zobaida, M.R., Yeasmin, Y. and Islam, A.K.M.M. (2016). Integrated nitrogen management of monsoon rice under two different plant spacings. Fundamental and Applied Agriculture, 1(3): 124-129.

Satyanarayana, V., Prasead, P.V.V., Murthy, V.R.K. and Rodty, K.J. (2002). Influence of combined application of farm yard manure and inorganic fertilizers on yield components of irrigated low land rice. Journal of Plant Nutrition, 25(10): 2081-2090.

UNDP and FAO. (1988). Land resources appraisal of Bangladesh for agricultural development. Report 2. Agro-ecological regions of Bangladesh. United Nations Development Programme and Food and Agricultural Organization. pp. 122-131.

Usman, M., Ehsa, U., Warriach, E.A., Muhammad, F. and Amir, L. (2003). Effects of organic and inorganic manures on growth and yield of rice variety "Basmati-2000". International Journal of Agricultural Biological, 5(4): 481-483.

Vajantha, B., Reddy, K.S. and Napdu, M.V.S. (2012). Effect of integrated nitrogen management of physiological parameters and yield of maize. Agricultural Science Digest, 32(4): 286 -290 .

Yeasmin, S., Islam, N. and Sarker, M.A.R. (2009). Effect of integration of fertilizer and manure on the performance of Boro rice under the system of rice intensification. Bangladesh Journal of Crop Science, 20: 157-164. 